Studia UBB 田igitalia, Volume 62 (LXII) 2017, December, Issue 2, 35-62

Published Online: 2017-12-30

DOI:10.24193/subbdigitalia.2017.2.03

\title{
Computer oriented higher education in Hungary - the beginnings
}

\author{
Edit Sántáné-Tóth \\ Honorary Associate Professor \\ Óbuda University, Faculty of John von Neumann \\ Eötvös Loránd University, Faculty of Informatics \\ John von Neumann Computer Society
}

\begin{abstract}
The history of computer-oriented higher education in Hungary started in 1957, when Prof. László Kalmár started the education of "applied mathematicians" at the University of Szeged. (The author graduated in the second year of this course, later called the "Szeged School.") This paper starts with the computing experience around M-3, the first computer made in Hungary, and the use of this experience for educational purposes. It then continues with the initiatives of the University of Szeged, and, after surveying some basic and higher-degree courses, goes on to the institutions of higher learning offering education in computer studies, all the way to the programmer and program developer mathematician courses started in 1972 at three science-universities. However, the institutions of technical education will not be discussed in such detail; although teaching applied computing skills necessary for the technical field had begun quite early, the teaching of professional IT specialists was started only around 1990. The paper contains a table listing the first elective and founding subjects and the first specializations and independent training programmes offered by each university and college. Finally there is a short overview of the connections between contemporary professors and a list of the first conferences organized for IT teachers in Hungary.

The IT History Forum (iTF) within the John von Neumann Computer Society (NJSZT) was founded at the beginning of 2009. At one of its events, it occurred to the author that information about the beginnings should be gathered while the persons in question are still alive. The study took 3 years to prepare and is
\end{abstract}


the product of a large-scale collaboration: a total of 130 contemporary and present day teachers, researchers, and librarians participated in the work. Typotex published the material in the form of a book in 20121. This study, which provides insight into the everyday lives of 30 institutions, is the source for this paper. (The book includes a name-index containing 300 entries and a list of almost 500 definitive contemporary articles, textbooks and technical books published until 1980.) - The paper is concluded with a brief presentation of the digitalised "Data Archive" (see the iTF website: http://itf2.njszt.hu) that serves to preserve the history of computing in Hungary.

Keywords: History of informatics; M3; computer oriented education; John von Neumann Computer Society; history of computing in Hungary

\section{Preface}

In Hungary, the history of computer-oriented higher education started in 1957, when László Kalmár launched the Applied mathematicians course at the University of Szeged. (Later tis course was referred as "Szeged School"; the author herself graduated in the second year of it.)

By that time, work had commenced in Budapest on the first Hungarian-built computer, the M-3, which was put into operation in 1959. Developers and programmers of computer programs, as well as a group of professionals from universities and companies were responsible for setting the wheels in motion that led to the spread of computer skills in Hungary, and later to the institutionalised education of it.

Although there are reports that deal with the beginnings, it is the contemporary participants who can provide us with real detail. (Back then, there was no internetaccessible digitalized storage that would be able to preserve data of events, participants, etc.)

During an event held by the IT History Forum (iTF) - which was founded at the beginning of 2009 within the John von Neumann Computer Society (NJSZT) - the author thought of the idea of clarifying the events of these beginnings, while the persons in question are still alive. The leaders of the iTF embraced the idea and work started immediately on the study entitled "Computer Oriented Higher Education in Hungary -

\footnotetext{
${ }^{1}$ Edit Sántáné-Tóth: 'Computer Oriented Higher Education in Hungary - The Beginnings'. Typotex, Budapest, 2012. p. 366. http://www.interkonyv.hu/konyvek/santane toth edit a szamitastechnika felsofoku oktatasanak kezdetei
} 
The Beginnings", which used documents and the (sometimes contradictory) recollections of witnesses to provide an overview of the beginnings as accurately as possible. The iTF held a total of four events in 2010 and 2011 about this history (conveying the words of contemporary participants), during which events the amount of materials, the level of authenticity, and the number of active participants all increased.

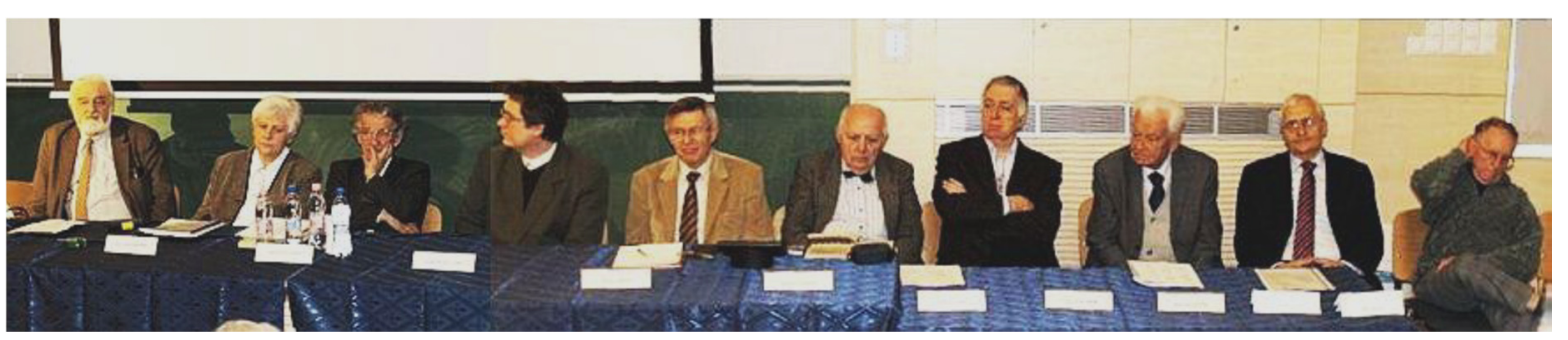

Figure 1: Lecturers at the 11 March 2010 event on the institutions that offered computer education by 1971 (from left to right): Bálint Dömölki, Edit Sántáné-Tóth, János Szelezsán, Péter Gábor Szabó, Péter Hunya, Győző Kovács, János Csépai, Lajos Ivanyos, Dezső Sima, Ferenc Gémes, and, amongst the attendees: Sándor Faragó and Gábor Kógelmann.

At the outset, the aim was to provide a true history of the "Szeged School", which was naturally followed by work on providing a comprehensive Hungarian overview. However, in the interim, we had to face the fact that the only persons truly capable of providing factual accounts of what happened half a century ago are those who (at least tangentially) participated in the events. This led to intensive correspondence to seek out living witnesses.

Information was compiled first on the beginnings in Hungary, then on the institutions that started independent training in the field of computer sciences by 1971 . The collection of materials on education started by 2012 at three science-universities was also commenced, and interviews were made. Sixty enthusiastic persons helped in developing the first version of this study, which was finished by the end of 2009. Its 1 st part contains reports on the various institutions in the order of offering independent training. The time-limit of our history is 1980 , since by that time computer science (informatics) had generally taken its place in higher education and the basic structure of education of computer studies had taken on its form.

The version of the study finished in February 2010 was uploaded to the NJSZT-iTF website to provide interested professionals with an opportunity to discuss the material (after which the file was updated monthly). The feedback received, and more correspondence allowed us to contact still more contemporary witnesses and people who could help; with them, the study's message became increasingly diverse and rich. 
Intensive work soon commenced to research the histories of the missing higher education institutions. By contacting the friends of friends and writing many letters asking for favours, we managed to find witnesses who undertook to gather together their memories on the beginnings of computer-oriented education. These included people who committed themselves to locate the contemporary documents, accept my participation as editor, and write the contemporary history of their respective institutions. Thus, the second and third parts of the material are about those higher education institutions where we were able to compile histories through intermediaries or from contemporary documents. In order to meet their special educational targets, these institutions included, far before 1972, the computer-related information required for education of the involved fields at the time, though they only launched these specialisations and courses at a later time.

The material prepared after much consultation is a collective creation: a total of 130 contemporary and present teachers, researchers, and librarians participated in the work. However, despite of all these endeavours, it still does not provide a complete picture of the beginnings of computer-oriented higher education in Hungary. There are significant higher education institutions (e.g. law and medical universities) that we did not deal with. In absence of substantive information, we therefore do not provide information on their first steps. However, we can definitely say that the work does provide a good overview of the beginnings in Hungary: the respectable fight of contemporary teachers and their supervisors to introduce new computer-oriented subjects, compile the first curricula, acquire the first computers, and launch the various new sections, specialisations, and courses (To quote Gyula J. Obádovics: "Only try to introduce a new subjects if the gods are on your side."). In all cases, the authors attempted to provide authentic descriptions to the greatest possible extent.

Meanwhile, the need arose to compile a list of contemporary technical books, higher education textbooks, and notes (published until 1980). A list of 300 people included in the material was also drawn up (even though we realise that only a part of the contemporary actors could be named). Four tables at the end of this paper summarise the first elective and founding subjects and the first specialisations, sections offered by each university and college. The paper also deals with the connections between contemporary teachers of computer sciences (based on correspondence and personal meetings), as well as the first conferences and events they held.

\footnotetext{
${ }^{2}$ Gyula J. Obádovics's book entitled Mathematics has been used for generations and is simply referred to as "The obádovics." Thanks to his textbooks, we consider him to be one of the founders of computeroriented education in Hungary.
} 
The three parts of the book published by Typotex in 2012 provides insight into the lives of 30 institutions - including a brief history of the various institutions. These institutions naturally include those dealing with holding training courses, postgraduate courses, and other special continuing education. The work summarises the events in computer-oriented/IT education that transpired at universities and colleges in the form of four tables (a brief version of which is also included herein).

The present paper provides a short overview of the beginnings of computeroriented education in Hungary. Chapter 1 provides an insight into the lives of institutions that launched separate computer-related courses by 1972 - with some more detail provided about the institutions in which the author studied or taught. Chapter 2 presents some interesting solutions and experiments in teaching programming methodology. Chapter 3 gives a short outline of the beginnings of Hungarian technical universities and colleges. Chapter 4 contains the four summary tables mentioned above and the conclusions that can be drawn from them. Chapter 5 deals with the relationships and the first conferences of contemporary lecturers. The conclusion discusses the iTF Data Archive and its Persons section.

\section{From the cradle to the institutions that launched computer-related courses by 1972}

Two large directions can be found in the development of computing in Hungary: the branches of computer science (as we did say then: cybernetics) and of administrative data processing.

- The first prominent product produced by the computing branch was the first Hungarian computer, the M-3, which was built by the Hungarian Academy of Sciences' (MTA) Cybernetics Research Group (KKCS) in 1957. László Kalmár of the University of Szeged took the second step in this direction: with the foundation of the "Szeged School", he preceded the other higher education institutions in spreading and teaching mathematical logic and computer science in Hungary.

- The administrative data processing branch is linked to the Central Statistical Office (KSH), as, starting from 1953, it supervised the distribution of punch card machines that met the data processing needs of the time, as well as the connected training, information, and central purchasing. In the 1960s, the KSH also organised computer training courses, too (since the need arose).

The following is an overview of the lives of the institutions that launched computer science courses by 1972. (The Hungarian acronyms of the English names are provided in parentheses to allow for identification.) 


\section{a) Cybernetics Research Group of the Hungarian Academy of Sciences' (MTA KKCS)}

The research Group played an important role in the introduction of computing to Hungary and in its popularisation. The first programmers were the very people who built the M-3, though many users and teachers who later came into contact with it had their first computing experiences thanks to the M-3. Since this was the only operational computer in Hungary at the time, the first students of the Szeged School also spent their technical practice with, and wrote their theses on, the M-3. The training course entitled "Programming the M-3 electronic computer" was organised in 1958-59: it consisted of 37 lectures held by the employees of the Research Group. Many of the almost fifty participants of the lecture series became renowned computing experts, leaders, and teachers in Hungary.

The Research Group's employees regularly held informative lectures and seminars for secondary school students. Many colleagues also held regular lectures and seminars in higher education institutions. Thus, we are right to say that the Research Group was the cradle of Hungarian computing education.

In 1963, the Researcher Group's employees organised the Special Department for Information Processing, Cybernetics, and Operational Research within the Union of Technical and Natural Science Associations (MTESZ). - It should also be noted that this Department was one of the predecessors of the John von Neumann Computer Society (NJSZT) established in 1968. - They organised successful conferences with the title "Computer Technology" in 1968, 1971 and 1974.

\section{b) University of Szeged (SZTE) - later Attila József University (JATE)}

As mentioned earlier, the first computer-oriented education in Hungary was provided in the University of Szeged under the leadership of László Kalmár ${ }^{3}$ in the first semester of the 1957/58 school year. However, that is not where this story begins. He was first interested in mathematical logic in the 1920s and then turned to computer science in the 1950s. He undertook the fight to introduce these sciences to Hungary.

In 1956, László Kalmár organised his famous seminar at the University's Bolyai Institute ${ }^{4}$, targeting the technical and other applications of mathematical logic and cybernetics. During the course of the above, he designed the Kalmár's logical machine

\footnotetext{
${ }^{3}$ In 1996, László Kalmár's oeuvre was recognised by the Institute of Electrical and Electronic Engineers (IEEE) by the Computer Pioneer Award, given to pioneers in the history of computer sciences. (In 1996, the IEEE broadened its scope to include computer pioneers from Central and Eastern European countries in its award, (posthumously) granting it to 19 prominent figures, including László Kozma - see below.)

4 The Bolyai Institute in Szeged was awarded the Hungarian Heritage Award in 1997.
} 
in 1957. (The machine was presented at the University on 1 May 1958.) This was the environment in which László Kalmár's formula-driven machine and Dániel Muszka's Electronic Ladybird were created. ${ }^{5}$

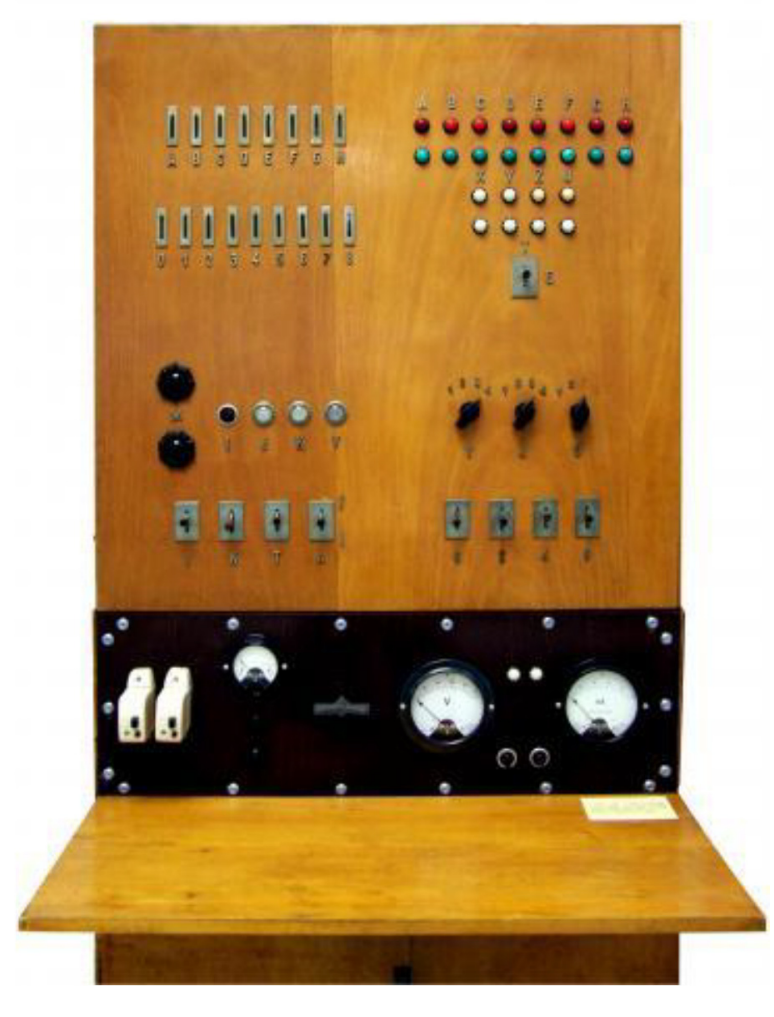

Figure 2: The Kalmár's logical machine

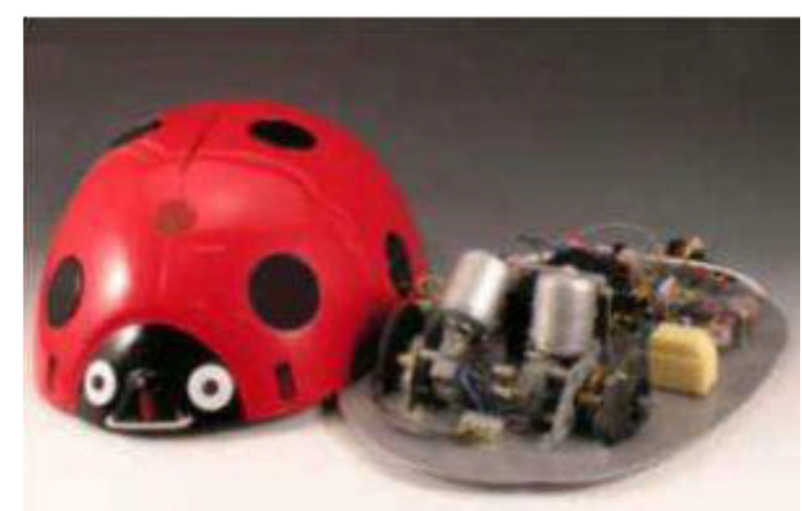

Figure 3: Muszka's Electronic Ladybird

\footnotetext{
${ }^{5}$ The Kalmár Logical Machine and Dániel Muszka's Electronic Ladybird were presented at the Budapest Industrial Show in 1960 to resounding success.
} 
The work on the seminar led to the development of a strong body of teachers. László Kalmár, the enthusiastic teacher and born propagator of the knowledge, soon realised that the time was ripe to launch the education of experts in applied mathematician and computer programming at the University. He fought to receive the Ministry's approval for 5 percent of the third-year teaching students who were studying two courses "to leave one course and continue more in-depth studies in a special area of their remaining course". For the first time in Hungary, the Applied (computer) mathematics course was launched in Szeged in the fall of 1957 - with 3 students. Thus commenced the operation of the "Szeged School". At the outset, the in-depth knowledge was imparted upon students in the framework of the Programming of Automatic Computers and the Numerical and Graphical Methods subjects.

We would also like to note that from the 1963/64 school year, the Szeged School was started from the very first year. However, the number of students never reached 15 in any one year. (The degree to which this failed to satisfy the needs of the market at the time is shown by the fact that the total of 9 students who graduated in the 1968/69 school year could choose from among 61 jobs.) At first, students could only access a computer in Budapest; they wrote programs on chalkboards ("chalk programming") and ran the programs in their heads. Then, in 1963, the Cybernetics Laboratory was established under the leadership of László Kalmár. This initially used the M-3 computer and was able to provide the computer background for teaching and research on-site.

\section{c) Computing Teaching Centre (Számok)}

The story behind the establishment of the Számok in 1969 is entirely different. By that time, the government had realised that several thousand new computer experts were now required every year. It therefore commissioned the Central Statistical Office, which had experience in the field of administrative data processing, to launch the appropriate trainings and to provide for the details of this task. It ended up creating Számok and entrusted Sándor Faragó with its management. (Besides developing curricula and the examination system, Számok also dealt with the publication of technical books on computing.) Control Data Corporation (CDC), known at the time for its top-of-the-line computers and its training branch, provided the know-how - under a grant from United Nations Development Program (UNDP). As there was no teaching body, a tender was announced for mathematicians, engineers, and economists who spoke English at least at an intermediate level (500 applications were received for the 43 positions). After an intensive two-month English language course, then the selected young people participated in half-year (programming, computer engineering, and systems manager) training at CDC's training centre in Frankfurt. 
Számok started the education in the autumn of 1971. Their successful trainings even took them to other (mainly Arabic) countries. As a point of interest, we would like to note that the so called rotation system was launched in 1973 for teachers. First, they created a practical workshop to perform organisation tasks for third-party orders. Then, teachers were required to regularly (once a year) participate in the workshop's activities - to ensure their practical work was founded on experiences.

By way of its various levels of trainings (and courses), Számok was the first to provide an organised format for lifelong learning. For example, they were the first to offer computing-oriented postgraduate courses for experts with university/college degrees. Finally, we would also like to mention the TV-BASIC training series aimed at popularising computing, launched in the beginning of 1980 together the NJSZT and the Hungarian National Television. This training provided a certificate after a successful exam.

\section{d) Karl Marx University of Economics (MKKE)}

At the initiative of Béla Krekó the Plan-mathematician economist course was launched at the University of Economics starting from the 1960/61 school year. The course aimed to provide experts with thorough macroeconomic skills and experience in the application of mathematical methods and the involved computing skills. About 150 Plan mathematicians had graduated by 1972 , and they were highly sought after on the labour market. The Economic mathematician specialisation launched in 1968/69 was a continuation of this training. In addition, the University also introduced a 4-semester computing subjects (and was the first to do so in Hungarian higher education) in the $1971 / 72$ school year, which was compulsory for all first and second year students.

It should be noted that the University Computing Centre was established in 1964 as the basis of University computing education and the institutions' research and development activities. The Centre was housed in the University, and for good reason: Béla Krekó played an essential part in its creation and operation. The Computing Centre was thus available (on-site) for Plan mathematicians.

\section{e) Kálmán Kandó Electrical Engineering Technical College (KKVMF)}

In 1968, Lajos Ivanyos prepared a recommendation at the College for launching higher education for the computer experts (more specifically, computer operators) required by Hungarian computer centres. After reworking the proposal (and after certain reorganisation at the College), the Computer technician course was launched in the 1970/71 school year with 31 students. Furthermore, starting from the second half of the 
$1970 / 71$ school year, computer sciences were also taught to all students at the Faculty of Colleges. In 1975, the teaching of the Computer technology tools course was moved from Budapest to the College's Off-Campus Division in Székesfehérvár - all to meet the demand of the Videoton computer manufacturing plant in Székesfehérvár.

It is also important to note that the Engineering informatics course that was launched for the first time at a Hungarian college in the 1988/89 school year by the College's successor (Kálmán Kandó Technical College, KKMF) formed the basis of the Engineering informatics courses introduced at 1988/89 - Hungarian colleges.

\section{f) College of Metallurgy- and Metal-Industry of Dunaújváros (KFFK)}

Ever since its establishment in 1969, the purpose of the College Faculty was to meet the demand of the Danube Iron Works in Dunaújváros. It must first be noted that the Iron Works' Operations Research Group had already been dealing with using computers for metallurgical applications under the leadership of Ferenc Gémes since 1961. (The author herself worked here for 9 years). However, due to a lack of computers in Dunaújváros, the number of persons in the Group decreased after 1971 - several left to research institutions while others went to teach at the College.

The latter experts already had ten years of experience in solving practical problems, and were able to launch a successful System engineer course in the 1971/72 school year. Starting from the same school year, all of the College's students were required to study the basics of computing. They were later provided access to a computer, compatible with computers acquired by the Iron Works that provided both to the College and to the Iron Works a great deal of security. Finally we note that the College established the Engineering informatics course referred to above in the 1992/93 school year.

\section{g) Eötvös Loránd University (ELTE)}

Computing education at the ELTE was commenced from the mid-1960s integrated ("smuggled") into certain subjects (e.g. analysis lectures and the mathematics classes of chemistry and physics students), and regarding which seminars and special classes were held, after which it became an elective and finally a separate subject. The curriculum already had a computer-oriented subject in the first semester of the 1957/58 school year. In the 1971/72 school year, Computer sciences was a compulsory subject for 2 semesters at ELTE's Faculty of Natural Sciences. In the interim, work started and led to the launching of the Programmer mathematician course in the 1971/72 school

\footnotetext{
${ }^{6}$ It was then a Faculty of Heavy-Industry Technology University (NME).
} 
year - in accordance with the curriculum agreed on with other universities. The details of this will be discussed below. (It should be noted here the Computational linguistics course was started in the 1962/63 school year at the General Linguistics Department at ELTE's Faculty of Humanities.)

\section{h) Lajos Kossuth University (KLTE) - in Debrecen}

At the University of Debrecen the head of the Mathematicial Institute, Béla Gyires realised early on that the global surge in the development of computer sciences meant he had an urgent task. In 1963, he sent two of his teachers to the Cybernetics Research Group (mentioned above) to study the operation and programming of the M-3. Upon returning from Budapest, they immediately started developing a computer curriculum and organising education.

For years, teaching took the form of theoretical lectures only (in absence of a computer, they used "chalk programming", just like in Szeged). In 1967, they finally received an Odra-1013 computer. They organised trainings for university professors and, starting in 1971, even held computer continuing education in the summers for secondary school teachers. Meanwhile, they also joined the works undertaken to prepare for the Programmer mathematician course described below.

The following is the history of the development of the Programmer mathematician (and later the Program developer mathematician) courses offered by the three Hungarian science-universities (ELTE, and the universities of Szeged and Debrecen) starting from the 1972/73 school year.

By the 1970s, there was quite a variety of computers in Hungary, and it was becoming increasingly clear that, in addition to operating and programming computers, the development of computer programs required special technical skills. People recognised that higher level education had to be provided en masse to professionals with these skills (Számok was not, and could not have been, responsible for this task).

The idea that ELTE could train programmers who were at home in program development and had suitable mathematical modelling foundations came naturally. Towards the end of the 1960s, there were already some attempts at this at the University (though these were vetoed by certain mathematicians).

The Government in 1968 prepared the Central Computer Development Program (SZKFP), which was supervised by the Ministry for Culture. The Ministry requested (instructed) the three Hungarian science-universities to provide basic computer training 
to the majority of the students of their Natural Science Faculties and to aid researchers in using computers and computing skills. In connection with these tasks, ELTE established its Department of Numerical and Computer Mathematics in 1968.

The Ministry's commission on mathematics discussed the need for launching college-level computer education several times. Since the Ministry was not opposed to the idea, the experts at the three universities started developing the training program. A committee with four members (László Kalmár, Imre Kátai, József Mogyoródi, and János Szelezsán) was quickly set up at ELTE to initiate a Programmer mathematician course at ELTE's Faculty of Natural Sciences, which would provide strong modelling skills.

In the beginning of the 1970s, the Ministry then requested the three universities to develop a program for computer oriented higher education. ELTE's Department of Numeric and Computer Mathematician, led by Imre Kátai, was given this task. ELTE's representatives in the above committee would have liked to launch a training program similar to that of the Szeged School, but László Kalmár stood his ground and protected Szeged's interests. At first, the university of Debrecen (represented by Béla Gyires) was also opposed to the initiative, as they did not feel that such experts were guaranteed a possibility of finding jobs. However, Imre Kátai devoted his efforts with unheard of dynamism to organise the new course. Meanwhile, the experts at the university of Debrecen processed the computer curricula of universities in neighbouring countries, which led to the harmonised curriculum and the Ministry for Culture's Instruction No 119/1972 (M.K.9) on the introduction of the three-year programmer mathematician training:

"Starting from the 1972/73 school year, the mathematics courses offered by science-universities will also be host to three-year education courses providing an education as a programmer mathematician. After completing their studies and passing the final State examinations, such students will receive a 'Programmer mathematician' college-level degree. This Instruction shall enter into force on the day of its publication. The involved parties shall directly receive the curriculum of the Programmer mathematician course."

And so the Programmer mathematician course was launched at the three universities in the $1972 / 73$ school year. This course later (first at ELTE) provided the basis for a 2-year Program developer mathematician course that provided a university-level degree - thus implementing a unique, two-tier university-level education that was successfully used for 35 years. Although the Program developer mathematician course was launched in 1979 at the university of Szeged, the Szeged School continued its functions without any manner of transfer between the two. The Program developer mathematician course was started at the university of Debrecen only in 1988. 
In response to social pressure, ELTE soon launched the Program developer mathematician course in the form of evening classes. This meant that the people who started working after receiving their college degree following their 3 rd year could get a university degree by taking evening classes.

Starting in 2000, in the spirit of the Bologna process, Hungarian universities carried on with this unique (two-tiered) university level training by introducing a twotiered system starting with a college-level (not a university-level!) (BSc) and ending with a 2 year university-level (MSc) education.

\section{Some special Hungarian methods of teaching programming}

By 1959 Hungary had two Ural-1 type computers in addition to the M-3. All three computers were located in Budapest, forcing students in Szeged to write programs using paper and pencil or chalk and chalkboard and to run programs in their heads (later called "dry runs"). Since it could be expected that newer types of computers would be purchased, it was not considered expedient to teach computer programming on any one machine. In order to be able to present the various programming steps as clearly as possible, Prof. László Kalmár at the university of Szeged taught computer programming methods on the so-called Kalmár's fictive computers. The three-addressed (and later the single- and double-addressed) machines that he defined unified the features of the respective computer types, thus showing what could be the (dis)advantages of any given command. When they were able to access an actual computer, students had to first assess the features of the specific type that were in common with the fictive machine; afterwards, they were able to apply the learned programming techniques relatively quickly.

However, in 1960 he realised that these specific sets of commands used to drive the fictive machine were also limiting his scope. From that time on, he defined unique commands (add, subtract, move, go to, etc.) that were independent of each other instead of fictive machines (equipped with command sets). (Moreover, the practical classes gave students the opportunity to learn about all the specific computers that they received specifications for.) A great disadvantage of programming with fictive machines is that the program could not actually be run (which is not a particular setback compared to the fact that - in lack of any computers - students could not run their programs written for any specific computer). This was literally chalk programming, which did not give students the experience of running a real program, and the didactic advantages of rerunning a program after error correction could also not be utilised.

The appearance of high-level programming languages naturally brought about a new situation. Just as in the case of mathematical terms, Kalmár strived to make 
teaching as visually stimulating as possible, for example illustrating cycle commands with a servant carrying water in a can and the changes in cycle variables with the number of pebbles removed by the servant one by one. He taught ALGOL 60 and later ALGOL 68 with a unique graph method called flagged figures. This allowed to provide a better understanding of the given language and the structures and workings of the various programs, thus also helping in checking and debugging the programs.

Finally, we would like to note that László Kalmár considered it important to teach using tangible objects that helped understand actual practical tasks and gave a life-like approach. That is why experimental physics (and the accompanying subjects) were not left out of the Szeged School even when the applied mathematics course could be elected as a secondary course starting from the 1st year.

The following is a presentation of the idea of Ákos Fóthi's, a professor at ELTE, which led to the founding of a school. He taught the basics of high-level programming (instead of presenting the solutions used by the specific programming languages) by approaching it from the direction of abstract programming based on relational programming models. After the Programmer mathematician course was set on its way in the 1972/73 school year, he soon developed the characteristic method for teaching the Programming methodology (also called Introduction to programming) subject, which was consistently followed. The subject dealt with the examination of the theoretical background behind the methods instead of the methods used to create programs: "Programming methodology is a theoretical subject and is part of programming theory: it deals not with the characteristics of various programs, but with the theory of problemsolving," - wrote Ákos Fóthi. So the essence is its task-centric nature, i.e. the analysis of the problem to be solved. As a result, he uses the definition of relations, and not the term of functions, as his basis (since the execution of parallel programs is nondeterministic). According to Fóthi, the task is a relation that orders points of a state space to the points of a state space while a program maps a series of points of a state space to the points of a state space. As the end result, the program gives the endpoint(s) of such series, which is 10 called a program function. On its basis, it can be determined when a program is a solution to the given task. An important element of the subject is that it provides more than one program (program function) for a task - and also helps prove the correctness of the program.

To quote the opinion of one of Ákos Fóthi's students", "I think that anyone who does not consider the Introduction to programming subject to be important, or considers it outright pointless, is missing the point. It provides students with a number of principles

\footnotetext{
${ }^{7}$ http://www.markmyprofessor.com/tanar/adatlap/8880.html
} 
that can be used for programming and also helps understand terms that you meet during programming. It also teaches you to think logically and shows you just what it means to prove that a program is correct."

\section{On the computing education of technological education institutions}

In the 1960s the technical colleges and universities launched application-directed, so-called applied computing subjects wishing to meet the demands of the market. The purpose of education was to train students who had the computing skills required for their professions, had a good command of the problem-solving approach specific to their fields of expertise, and were able to apply the computing skills in their problemsolving. These institutions provided technical courses with specialised computer training, called Engineering informatics held at the Budapest Technology University (BME) Faculty of Electrical Engineering standing out from the crowd by the end of the 1980s, which, following in the footsteps of the Kálmán Kandó Technical College's (KKMF) Engineering informatics college-level course (mentioned in Chapter 1), led to the launch and subsequent spreading of Engineering informatics education in Hungary. Because of the above (and in order to save space) we will be dealing only with the beginnings of the BME's Faculty of Electrical Engineering; Tables 2-4 in Chapter 4 provide information on the first steps of the remaining technical education institutions.

Organised computer training was launched at BME's Faculty of Electrical Engineering (VIK) in the 1960s. By the 1970s, the computer-based approach had become widespread in technical subjects. The purpose of education was focused on teaching the use and programming of computers as well as the skills related to the development and operation of computer tools and equipment.

László Kozma ${ }^{8}$, one of the Faculty's founders and the creator of the first programmable computer that used relays, the MESZ-1, should be the first to be mentioned.

Between 1956 and 1958, László Kozma designed and built the MESZ-1, the first Hungarian programmable computer that used relays (see Figure 4.). It was put into operation in 1958. This machine was used in education and for scientific research for ten years. It was found to be quite advantageous for teaching purposes: since it was comparatively slow, its operations could be followed visually.

\footnotetext{
${ }^{8}$ In 1996, László Kozma's oeuvre was recognised by the Institute of Electrical and Electronic Engineers (IEEE) by the Computer Pioneer Award, given to pioneers in the history of computer sciences. (In addition to the creation of the first Hungarian programmable computer using relays, the reason for the award included the creation of a special computational linguistics computer for the MTA Research Institute for Linguistics. In recognition of his earlier work, they also mention the fact that he worked on developing electric calculators at the Bell Telephone Manufacturing Company's laboratories in Antwerp between 1938 and 1942; ten patents attest the successfulness of his work.)
} 


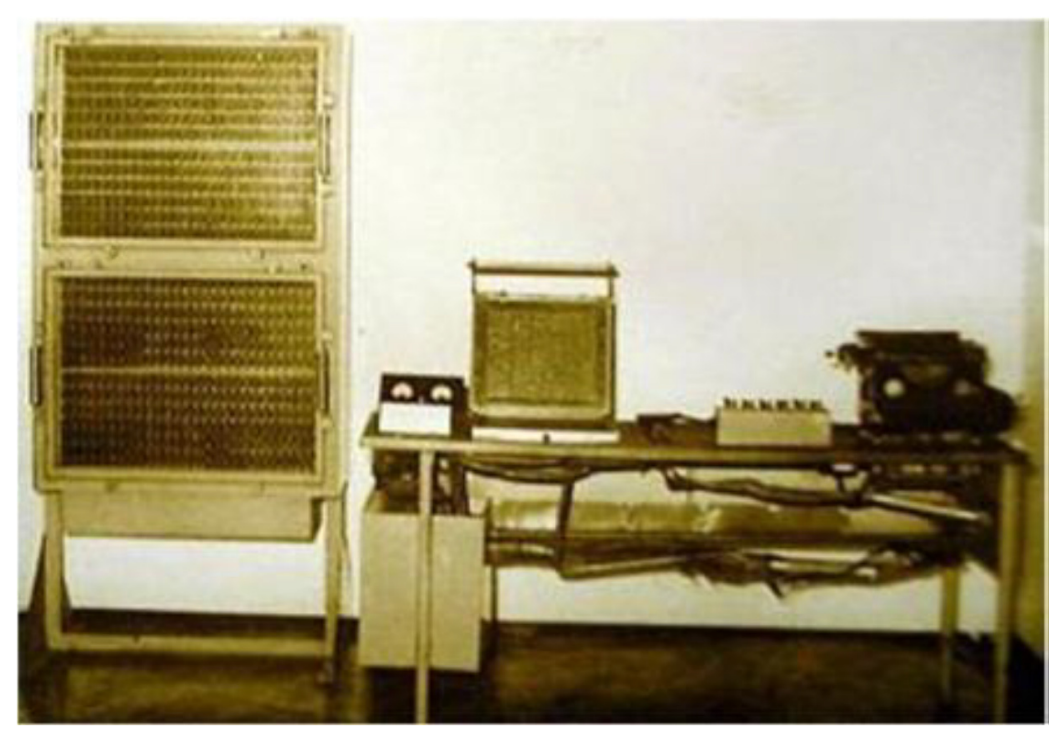

Figure 4: Kozma's MESZ-1

In addition to designing arithmetic circuits, computational circuits, and others, László Kozma's classes on logic circuits and telecommunications networks undoubtedly also discussed computer programming as well, which can thus be considered the first instance of computer education at the Faculty.

The strict curricular education used at the University delayed the introduction of computer training at all of its faculties. The rules of the University stated that the entire curriculum for the whole duration of the course (i.e. five years) had to be prepared by the time the course started. Thus, when a need arose to implement a change, several years had to pass before an introduced reform affected the entire student body and all courses of the given faculty. However, teachers were driven by the desire to teach students about computing.

Starting from the 1959/60 school year, the Faculty of Electrical Engineering provided a possibility for starting institutionalised computer education by announcing elective subjects and alternative subjects, which latter were available to certain, typically fifth-year students. (In this case, the alternative subjects meant that one or two had to be selected in the given semester from 2-10 possibilities.) Special subjects of computer science were made compulsory starting from the 1964/65 school year. Afterwards, they launched six computer-oriented specialisations in the beginning of the 1970s, which were also applied in the education of computer engineers. Of these six, the subjects found to be useful and worthwhile were then included in the Faculty's regular curriculum after a delay of a few years (within the framework of the rigid curriculum requirements). Computer sciences were naturally included in the various technical subjects quite early on (just as at ELTE). 
The industry - and thus the market - set an increasingly strong demand for the education of professionals with a thorough knowledge of informatics and adept at solving the problems incurred in the given sectors. With this external demand, the teaching of information technology-oriented subjects at technical education institutions also underwent strong internal development. As a result, the Faculty was the first in Hungary to introduce a (university-level) Informatics course in the second semester of the 1986/87 school year. The course first had 75 first-year students who had transferred from other courses. Starting from 1987/88, students were accepted based on acceptance scores.

The continuous increase in user requirements regarding informatics education made it necessary to create an independent Informatics course that carried the same weight as the aggregate of electrical engineering courses and that could not be thematically linked to electrical engineering but had a separate curricular structure equal in rank to those of electrical, mechanical, chemical, etc. engineering courses.

The first year of the Engineering informatics course was launched at the Faculty in September of the 1991/92 school year. (The students who graduated from the Informatics course were already given Engineering informatics degrees.) At the same time, the Informatics course was terminated and the electrical engineering education was continued in a new system. As the years passed, the number of students at the Engineering informatics course reached and then exceeded the total number of Electrical engineering students. (12)

\section{Characteristic features of Hungarian universities and colleges}

The diversity of the composition, interests, technical background, and connections of the respective teaching staff at Hungarian education institutions provided for different topics, even at identical times. The objectives of the computer courses launched at almost identical times, their institutional conditions, the selection of guest lecturers available to hold special lectures and the targeted market were different.

There is even a difference in the method by which the institutions introduced computer education. For example, ELTE and the university of Debrecen started off by integrating it into certain subjects in the form of seminars and special classes from the mid-1960s, after which it became an elective and finally a separate subject. There were numerous such initiatives at the various faculties of the Budapest Technology University (BME) as well; however, the rigid BME curriculum regulations discussed in the previous chapter negatively affected incremental development. Here, computer subjects first made their appearance as alternative subjects: those subjects that were deemed successful and 
useful were included in the regular curriculum with a delay of several years. The situation was different where strong personalities who established schools, were capable of realising their intentions or where considerable external demand created a possibility for launching computer education that was independent from the outset - we will discuss some examples later.

The following Figure 5 presents the developed forms of computer education in Hungary according to type, level, and development process. It presents the developed forms of computer education in Hungary according to type, level and development process. (The initiator and one of the elaborators of this 3D state space was Dezső Sima, professor at Óbuda University.) - The X-axis summarizes (in chronological order) the earlier mentioned levels of education. The $\mathrm{Y}$-axis shows the evolving aim of the education - which led to two kinds of courses: the Program developer mathematician course (as kind of "Computing major" education) and as the final form of application-direction computing education, the Engineering informatics course (as kind of "Computing minor" education). The Z-axis shows the evaluation steps of kinds of education (see below the 2-5 columns of the surveying tables).

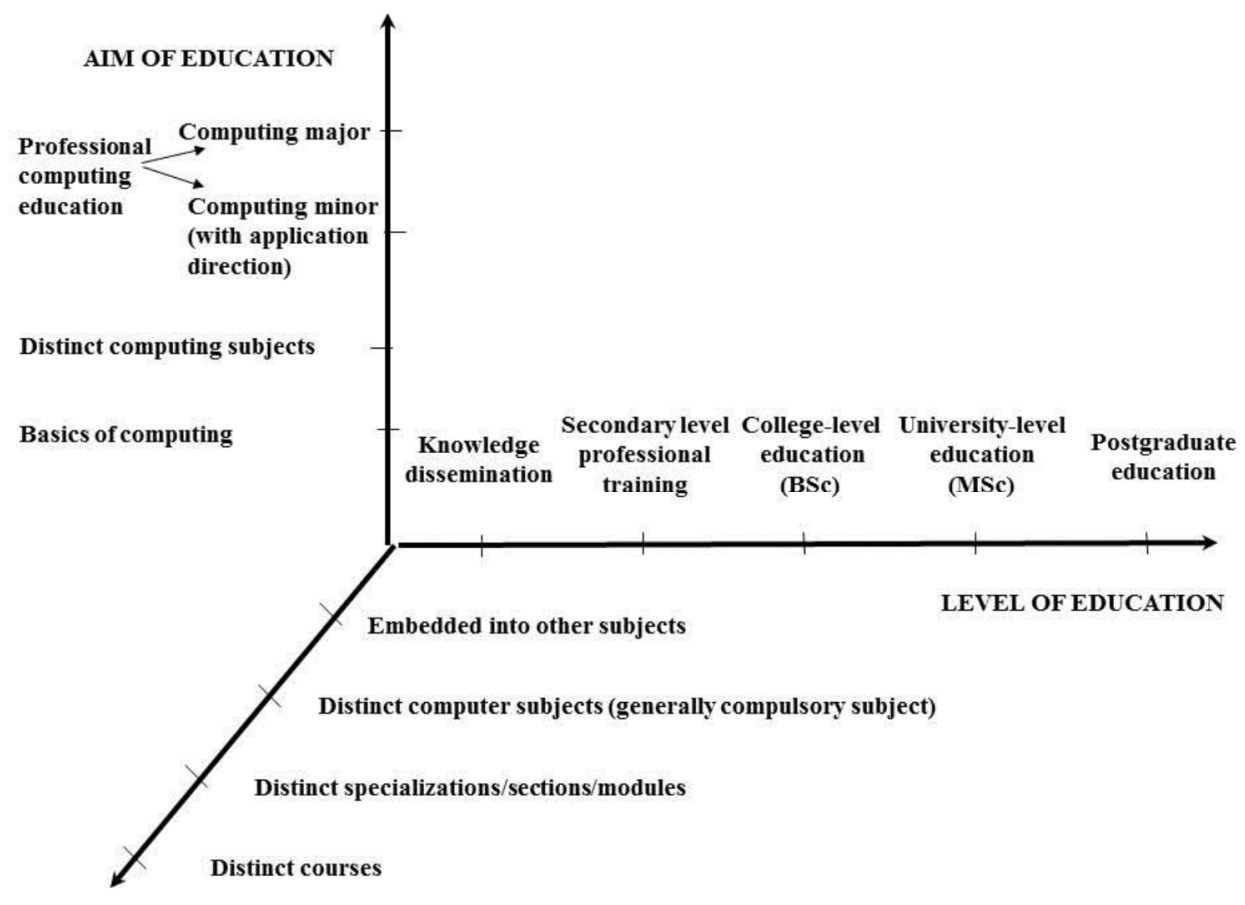

EVALUATION OF THE EDUCATION SYSTEM

Figure 5: The state-space of the evaluation of forms of education in Hungary 
The following tables provide a summary of the data characteristic of Hungarian universities and colleges and the main milestones of the development of computeroriented education (with dates):

- The first column contains the contemporary names of the various institutions, (in case of two science-universities the well-known direct successors). We also indicate (in parentheses) the present (2017) legal successor, where we use the Hungarian name to facilitate internet searches (websites have English versions); the book also names the earliest successor of each.

- The following columns show the steps in the development of computer-oriented education -from the first, facultative optional objects to the steps shown in the Z-axis of the Figure 5.

- Table 1 contains the data of the universities and colleges presented in Chapter 1 (in course-launching order).

- Table 2 shows data of the faculties of Budapest Technology University (BME) significant from the aspect of computer-oriented education.

- Tables 3 and 4 represent data of other universities and colleges (in alphabetic order).

Table 1: The first independent, computer-oriented university/college-level courses to be launched.

\begin{tabular}{|c|c|c|c|c|}
\hline $\begin{array}{l}\text { Contemporary name of } \\
\text { the institution (with the } \\
\text { present successor in } \\
\text { Hungarian) }\end{array}$ & $\begin{array}{l}\text { First, faculta- } \\
\text { tive optional } \\
\text { subjects }\end{array}$ & $\begin{array}{l}\text { First distinct sub- } \\
\text { ject (generally } \\
\text { compulsory subj.) }\end{array}$ & $\begin{array}{l}\text { First distinct spe- } \\
\text { cializations/ sec- } \\
\text { tions/ modules }\end{array}$ & First distinct courses \\
\hline $\begin{array}{l}\text { - 1945-1962: University of } \\
\text { Szeged (SZTE) } \\
\text { - 1962-2000: Attila József } \\
\text { University (JATE) } \\
\text { - (2000-: Szegedi } \\
\text { Tudományegyetem, SZTE) }\end{array}$ & $\begin{array}{l}\text { - 1957/58: } \\
\text { Programming of } \\
\text { automatic } \\
\text { computers } \\
\text { - 1957/58: } \\
\text { Structural } \\
\text { elements of } \\
\text { computers }\end{array}$ & $\begin{array}{l}\text { - 1971/72: } \\
\text { Computer } \\
\text { technique }\end{array}$ & & $\begin{array}{l}\text { - 1957/58: (III. year): } \\
\text { Teacher of mathematics } \\
\text { and applied mathemati- } \\
\text { cian course } \\
\text { - 1972/73: } \\
\text { Programmer } \\
\text { mathematician course } \\
\text { - 1975/76: } \\
\text { Program-developer } \\
\text { mathematician course }\end{array}$ \\
\hline $\begin{array}{l}\text { - 1953: Karl Marx } \\
\text { University of Economics } \\
\text { (MKKE) } \\
\text { - (2003-: Budapesti } \\
\text { Corvinus Egyetem, BCE) }\end{array}$ & & $\begin{array}{l}-1971 / 72 \\
\text { (2-years): } \\
\text { Basics of } \\
\text { computing - } \\
\text { the first time at } \\
\text { universities. }\end{array}$ & $\begin{array}{l}-1968 / 69: \\
\text { Economic } \\
\text { mathematician } \\
\text { specialization }\end{array}$ & $\begin{array}{l}\text { - 1961/62: } \\
\text { Plan-mathematician } \\
\text { economist course }\end{array}$ \\
\hline
\end{tabular}




\begin{tabular}{|c|c|c|c|c|}
\hline $\begin{array}{l}\text { Contemporary name of } \\
\text { the institution (with the } \\
\text { present successor in } \\
\text { Hungarian) }\end{array}$ & $\begin{array}{l}\text { First, faculta- } \\
\text { tive optional } \\
\text { subjects }\end{array}$ & $\begin{array}{l}\text { First distinct sub- } \\
\text { ject (generally } \\
\text { compulsory subj.) }\end{array}$ & $\begin{array}{l}\text { First distinct spe- } \\
\text { cializations/ sec- } \\
\text { tions/ modules }\end{array}$ & First distinct courses \\
\hline & & & $\begin{array}{l}\text { - Business } \\
\text { specialization }\end{array}$ & $\begin{array}{l}\text { - 1975/76: } \\
\text { Economic planning } \\
\text { course }\end{array}$ \\
\hline $\begin{array}{l}\text { - 1969:Kálmán Kandó } \\
\text { Electrical Engineering } \\
\text { Technical College } \\
\text { (KKVMF) } \\
\text { - 1991-2000: Kálmán Kandó } \\
\text { Technical College (KKMF) } \\
\text { - (2010-: Óbudai Egyetem, } \\
\text { OE) }\end{array}$ & & $\begin{array}{l}\text { - 1970/71: } \\
\text { Computer } \\
\text { technique }\end{array}$ & & $\begin{array}{l}\text { - 1970/71: } \\
\text { Computer technician } \\
\text { course } \\
-1979 / 80: \\
\text { Computer technician } \\
\text { systems c. (in Budapest, } \\
\text { Computer technique } \\
\text { tools course (in } \\
\text { Székesfehérvár) } \\
-1987 / 88: \\
\text { Informatics course } \\
-1988 / 89: \\
\text { Engineering informatics } \\
\text { course }\end{array}$ \\
\hline $\begin{array}{l}\text { - 1969: NME College } \\
\text { Faculty of Metallurgy- } \\
\text { and Metal-Industry of } \\
\text { Dunaújváros (NME KFFK) } \\
\text { - (2016-: Dunaújvárosi } \\
\text { Egyetem, DUE) }\end{array}$ & & $\begin{array}{l}\text { - 1971/72 (1-year): } \\
\text { Basics of } \\
\text { computing } \\
\text { - from 1974/75: } \\
\text { Computer } \\
\text { technique }\end{array}$ & $\begin{array}{l}-1971 / 72: \\
\text { System engineer } \\
\text { section }\end{array}$ & $\begin{array}{l}\text { - 1972/73: } \\
\text { System engineer course } \\
\text { - 1992: } \\
\text { Engineering informatics } \\
\text { course }\end{array}$ \\
\hline $\begin{array}{l}\text { - 1950-: Eötvös Loránd } \\
\text { University (ELTE) } \\
\text { - 1950-: Eötvös Loránd } \\
\text { Tudományegyetem, ELTE) }\end{array}$ & $\begin{array}{l}\text { - 1961: } \\
\text { Programming of } \\
\text { M-3 and Ural-1 } \\
\text { computers }\end{array}$ & $\begin{array}{l}\text { - 1957/58: } \\
\text { Theory of } \\
\text { computers, } \\
\text { Information theory } \\
\text { - (1971/72 (1 year): } \\
\text { Computing) }\end{array}$ & $\begin{array}{l}\text { - 1969/70: } \\
\text { Numeric and } \\
\text { computer mathe- } \\
\text { matician speciali- } \\
\text { sation - in the } \\
\text { Mathematician } \\
\text { course }\end{array}$ & $\begin{array}{l}\text { - 1972/73 (I.-III. years): } \\
\text { Programmer } \\
\text { mathematician course } \\
\text { - 1975/76: (IV-V. years) } \\
\text { Program developer } \\
\text { mathematician course }\end{array}$ \\
\hline $\begin{array}{l}\text { - 1949: University of } \\
\text { Debrecen (DE) } \\
\text { - 1952-2000: Lajos Kossuth } \\
\text { University (KLTE) } \\
\text { - (2000-: Debreceni } \\
\text { Egyetem, DE) }\end{array}$ & & $\begin{array}{l}\text { - From about } 1965: \\
\text { Programming of } \\
\text { M-3 computer } \\
\text { - (1972 in Faculty } \\
\text { level): Basics of } \\
\text { computing) }\end{array}$ & & $\begin{array}{l}\text { - 1972/73 (I.-III. years): } \\
\text { Programmer } \\
\text { mathematician course } \\
\text { - 1988/89 (IV.-V. years) } \\
\text { Program developer } \\
\text { mathematician course }\end{array}$ \\
\hline
\end{tabular}


Table 2: The development of computer education at BME's various faculties.

\begin{tabular}{|c|c|c|c|c|}
\hline $\begin{array}{l}\text { Contemporary name of } \\
\text { the institution (with the } \\
\text { present successor in } \\
\text { Hungarian) }\end{array}$ & $\begin{array}{l}\text { First, faculta- } \\
\text { tive optional } \\
\text { subjects }\end{array}$ & \begin{tabular}{|l|} 
First distinct sub- \\
ject (generally com- \\
pulsory subj.)
\end{tabular} & $\begin{array}{l}\text { First distinct spe- } \\
\text { cializations/ sec- } \\
\text { tions/modules }\end{array}$ & First distinct courses \\
\hline \multicolumn{5}{|l|}{$\begin{array}{l}\text { - 1949: Budapest Technol- } \\
\text { ogy University (BME) } \\
\text { - (2000-: Budapesti Müszaki } \\
\text { és Gazdaságtudományi } \\
\text { Egyetem, BME) }\end{array}$} \\
\hline $\begin{array}{l}\text { - 1949: BME Faculty of } \\
\text { Electrical Engineering } \\
\text { (BME VIK) } \\
\text { - (1992-: BME Villamos- } \\
\text { mérnöki és Informatikai } \\
\text { Kar, BME VIK) }\end{array}$ & \begin{tabular}{|l|} 
- 1959/60: \\
Computing \\
- 1959/60: Math. \\
problems of \\
analogous \\
computers \\
- 1964/65: \\
Development of \\
digital systems
\end{tabular} & \begin{tabular}{|l|} 
- 1964/65: \\
Automation and \\
computer \\
- 1969/70: \\
Programming of \\
computers \\
- (1971/72: Basics of \\
computing)
\end{tabular} & $\begin{array}{l}\text { - 1969/70: Digital } \\
\text { computing section } \\
\text { - in the } \\
\text { Telecommunications } \\
\text { course }\end{array}$ & $\begin{array}{l}\text { - 1963/64: } \\
\text { Control engineering } \\
\text { specialist - post- } \\
\text { graduate course } \\
\text { - 1986/87: Informatics } \\
\text { course (diploma: Engi- } \\
\text { neering informatics) } \\
\text { - 1991/92: Engineering } \\
\text { informatics course }\end{array}$ \\
\hline $\begin{array}{l}\text { - 1873: BME Faculty of } \\
\text { Architecture (BME ÉPK) } \\
\text { - (1973-: BME Építészmér- } \\
\text { nöki Kar, BME ÉPK) }\end{array}$ & $\begin{array}{l}\text { - 1961: ALGOL } \\
60 \text { instruction } \\
\text { study - for } \\
\text { teachers, too }\end{array}$ & $\begin{array}{l}\text { - (1972/72: } \\
\text { Computing - for all } \\
\text { students })\end{array}$ & & \\
\hline $\begin{array}{l}\text { - 1782: BME Faculty of } \\
\text { Civil Engineering (BME } \\
\text { ÉMK) } \\
\text { - (1782-: BME Építőmé- } \\
\text { rnöki Kar, BME ÉMK) }\end{array}$ & $\begin{array}{l}\text { - 1977/78: } \\
\text { Computers in } \\
\text { the hydrology } \\
\text { and hydraulics, } \\
\text { Computer- } \\
\text { controlled } \\
\text { systems }\end{array}$ & $\begin{array}{l}\text { - 1961/1962: (5. y.) } \\
\text { Electronics and } \\
\text { cybernetics } \\
\text { - (1963/64: } \\
\text { Electronic computers } \\
\text { - (1965/66: Basics of } \\
\text { computing) }\end{array}$ & $\begin{array}{l}\text { - 1965/66: Geodesic } \\
\text { automations train- } \\
\text { ing for lectures } \\
-1971 / 72: \\
\text { Applications of } \\
\text { computers spe- } \\
\text { cialization } \\
-1972 / 73: \\
\text { Computer tech- } \\
\text { nique section }\end{array}$ & \\
\hline $\begin{array}{l}\text { - 1871: BME Faculty of } \\
\text { Mechanical Engineering } \\
\text { (BME GPK) } \\
\text { - (1871-: BME Gépészmér- } \\
\text { nöki Kar, BME GPK) }\end{array}$ & $\begin{array}{l}\text { - 1970/71: } \\
\text { Computer } \\
\text { programming }\end{array}$ & $\begin{array}{l}\text { - (1971/72 (1 year): } \\
\text { Programming of } \\
\text { computers) }\end{array}$ & $\begin{array}{l}-1972 / 73: \\
\text { Computer tech- } \\
\text { nique section }\end{array}$ & \\
\hline $\begin{array}{l}\text { - 1955: BME Faculty of } \\
\text { Transport Engineering KMK) } \\
\text { - (BME Közlekedés-mérnöki } \\
\text { és Jármümérnöki. Kar, KSK) }\end{array}$ & & $\begin{array}{l}\text { - (1969/70: } \\
\text { Computer technique })\end{array}$ & $\begin{array}{l}\text { - 1971: Transport } \\
\text { system analysis } \\
\text { section - in the } \\
\text { Transport course }\end{array}$ & \\
\hline $\begin{array}{l}\text { - 1873: BME Faculty of } \\
\text { Chemical Engineering (VEK) } \\
\text { - (2006: BME Vegyész- } \\
\text { mérnöki és Biomérnöki Kar, } \\
\text { BME VBK) }\end{array}$ & $\begin{array}{l}\text { - 1968: } A L G O L \\
60 \text { programming }\end{array}$ & \begin{tabular}{|l|} 
- 1970: Basics of \\
computing -only \\
for teachers \\
- (1972/73: \\
Computer technique)
\end{tabular} & & \\
\hline
\end{tabular}


Table 3: The development of computer education at other Hungarian universities.

\begin{tabular}{|c|c|c|c|c|}
\hline $\begin{array}{l}\text { Contemporary name of } \\
\text { the institution (with the } \\
\text { present successor in } \\
\text { Hungarian) }\end{array}$ & $\begin{array}{l}\text { First, faculta- } \\
\text { tive optional } \\
\text { subjects }\end{array}$ & $\begin{array}{l}\text { First distinct sub- } \\
\text { ject (generally com- } \\
\text { pulsory subj.) }\end{array}$ & $\begin{array}{l}\text { First distinct spe- } \\
\text { cializations/ sec- } \\
\text { tions/modules }\end{array}$ & First distinct courses \\
\hline $\begin{array}{l}\text { - 1962: Academy of Mining } \\
\text { and Forestry (EFE) } \\
\text { - (2008: Nyugat-magyar- } \\
\text { országi Egyetem, NYME) }\end{array}$ & $\begin{array}{l}-1975 / 76: \\
\text { Computer } \\
\text { technique }\end{array}$ & $\begin{array}{l}\text { - (1977/78: } \\
\text { Computer technique })\end{array}$ & & \\
\hline $\begin{array}{l}\text { - 1957: Gödöllő University } \\
\text { of Agriculture (GATE) } \\
\text { - (2000: Szent István } \\
\text { Egyetem, SZIE) }\end{array}$ & & $\begin{array}{l}\text { - 1973/74: Computer } \\
\text { techn. (in Mech. eng.) } \\
\text { - (1979/80 (1 year): } \\
\text { Computer techn.) }\end{array}$ & & \\
\hline $\begin{array}{l}\text { - 1982: Janus Pannonius } \\
\text { University (JPTE) } \\
\text { - (2000: Pécsi } \\
\text { Tudományegyetem, PTE) }\end{array}$ & & $\begin{array}{l}\text { - (1972/73: } \\
\text { Computer technique } \\
\text { - for layers) }\end{array}$ & & \\
\hline $\begin{array}{l}\text { - 1949: Heavy-Industry } \\
\text { Technology University, } \\
\text { NME } \\
\text { - (1990: Miskolci Egyetem, } \\
\text { ME) }\end{array}$ & $\begin{array}{l}\text { - 1962/63: } \\
\text { Numerical } \\
\text { methods, } \\
\text { Practical } \\
\text { mathematics }\end{array}$ & $\begin{array}{l}\text { - (1964: (4,5 year) } \\
\text { Technical mathe- } \\
\text { matics - for mining } \\
\text { engineers) }\end{array}$ & $\begin{array}{l}\text { - 1966: } \\
\text { Applied } \\
\text { Mathematics } \\
\text { specialization. } \\
\text { - 1971: } \\
\text { System analysis } \\
\text { section }\end{array}$ & $\begin{array}{l}\text { - 1993: Engineering } \\
\text { informatics course }\end{array}$ \\
\hline $\begin{array}{l}\text { - 1951: Veszprém } \\
\text { University of Chemical } \\
\text { Engineering (VVE) } \\
\text { - (2006: Pannon Egyetem, } \\
\text { PE) }\end{array}$ & & $\begin{array}{l}\text { - 1967/68: Computer } \\
\text { technique } \\
\text { - (1970-1974 years: } \\
\text { Comp. technique - } \\
\text { for all students) }\end{array}$ & $\begin{array}{l}\text { - 1971/72 (2 year): } \\
\text { Chemical system } \\
\text { engineer section } \\
\text { - 1971/72 (3 year): } \\
\text { Chemical system } \\
\text { engineer section }\end{array}$ & $\begin{array}{l}\text { - 1973: } \\
\text { Organizing chemical } \\
\text { engineering curse } \\
\text { - 1988: } \\
\text { Automation } \\
\text { engineering } \\
\text { course } \\
\text { - 1991: } \\
\text { Engineering } \\
\text { informatics course }\end{array}$ \\
\hline $\begin{array}{l}\text { - 1955: Miklós Zrinyi } \\
\text { Military Academy (ZMKA) } \\
\text { - (2012: Nemzeti } \\
\text { Közszolgálati Egyetem, } \\
\text { NKE) }\end{array}$ & $\begin{array}{l}\text { - 1960: } \\
\text { Automation, } \\
\text { Information } \\
\text { theory - in air } \\
\text { defence training }\end{array}$ & $\begin{array}{l}\text { - 1965/66: Military } \\
\text { cybernetics } \\
\text { - (1967: Basics } \\
\text { of military } \\
\text { management) }\end{array}$ & $\begin{array}{l}\text { - 1968/69: } \\
\text { Operation } \\
\text { research lectures - } \\
\text { technique section }\end{array}$ & $\begin{array}{l}\text { - 1982: } \\
\text { REVA (System } \\
\text { organiser, } \\
\text { mechanization of } \\
\text { management and } \\
\text { automation) course }\end{array}$ \\
\hline
\end{tabular}


Table 4: The development of computer training at other Hungarian colleges.

\begin{tabular}{|c|c|c|c|c|}
\hline $\begin{array}{l}\text { Contemporary name of } \\
\text { the institution (with the } \\
\text { present successor in } \\
\text { Hungarian) }\end{array}$ & $\begin{array}{l}\text { First, faculta- } \\
\text { tive optional } \\
\text { subjects }\end{array}$ & \begin{tabular}{|l|} 
First distinct sub- \\
ject (generally com- \\
pulsory subj.)
\end{tabular} & $\begin{array}{l}\text { First distinct spe- } \\
\text { cializations/ sec- } \\
\text { tions/modules }\end{array}$ & First distinct courses \\
\hline $\begin{array}{l}\text { - 1969: Donát Bánki } \\
\text { Technical College } \\
\text { (BDGMF) } \\
\text { - (2010: Óbudai Egyetem, OE) }\end{array}$ & \begin{tabular}{|l}
$-1971 / 72$ \\
Programming \\
languages
\end{tabular} & $\begin{array}{l}\text { - 1972/73: Computer } \\
\text { technique }\end{array}$ & $\begin{array}{l}\text { - 1972/73: Computer } \\
\text { technique }\end{array}$ & $\begin{array}{l}\text {-1992: } \\
\text { Engineering } \\
\text { informatics course }\end{array}$ \\
\hline $\begin{array}{l}\text { - 1948: Teachers' Training } \\
\text { College of Eger (ETF) } \\
\text { - (1989: Eszterházy Károly } \\
\text { Főiskola, EKF) }\end{array}$ & $\begin{array}{l}\text { - 1972: } \\
\text { computing - } \\
\text { special lectures }\end{array}$ & $\begin{array}{l}\text { - (1972: Numerical } \\
\text { and computing } \\
\text { technologies) } \\
\text { - (1989: Basics of } \\
\text { computing) }\end{array}$ & & $\begin{array}{l}\text { - (1987-89: } \\
\text { development of } \\
\text { Hungarian curriculum } \\
\text { and program for } \\
\text { training of teachers) }\end{array}$ \\
\hline $\begin{array}{l}\text { - 1969: Technology College } \\
\text { of Engineering Industry and } \\
\text { Automation (GAMF) } \\
\text { - (2017: Neumann János } \\
\text { Egyetem, NJE) }\end{array}$ & & $\begin{array}{l}\text { - (1971/72: (1 year) } \\
\text { Basics of computer } \\
\text { technique) }\end{array}$ & $\begin{array}{l}-1971 / 72: \\
\text { Computers - } \\
\text { technical section } \\
-1971 / 72: \text { System } \\
\text { organiser section }\end{array}$ & $\begin{array}{l}\text { - 1991: } \\
\text { Engineering } \\
\text { informatics course }\end{array}$ \\
\hline $\begin{array}{l}\text { - 1972: Technical College } \\
\text { of Light Industry (KMF) } \\
\text { - (2010: Óbudai Egyetem, } \\
\text { OE) }\end{array}$ & & $\begin{array}{l}\text {-1970/71: } \\
\text { Controlling and } \\
\text { computing } \\
\text { - 1971/72: Com- } \\
\text { puter technique }\end{array}$ & & \\
\hline $\begin{array}{l}\text { - 1968: Transportation and } \\
\text { Telecommunication } \\
\text { College (KTMF) } \\
\text { - (2002: Széchenyi István } \\
\text { Egyetem, SZE) }\end{array}$ & & \begin{tabular}{|l} 
- (1971/72: Com- \\
puter technique) \\
- (1974/75: Basics of \\
computing and \\
programming)
\end{tabular} & $\begin{array}{l}\text { - 1971: Transport } \\
\text { technologies sec- } \\
\text { tion and Transport } \\
\text { system organiser } \\
\text { section } \\
\text { - 1987: Computer } \\
\text { technique section }\end{array}$ & $\begin{array}{l}\text { - 1970: } \\
\text { Transport- } \\
\text { cybernetics spe- } \\
\text { cialists course } \\
\text { - 1992: } \\
\text { Engineering } \\
\text { informatics course }\end{array}$ \\
\hline $\begin{array}{l}\text { - 1970: Financial and } \\
\text { Accounting College (PSZF) } \\
\text { - (2016: Budapesti } \\
\text { Gazdasági Egyetem, BGE) }\end{array}$ & $\begin{array}{l}\text { - } 1967 \text { basics of } \\
\text { computing - } \\
\text { special lectures }\end{array}$ & $\begin{array}{l}\text { - 1965/66: } \\
\text { Application of } \\
\text { organizing tools } \\
\text { - (1967: Computer } \\
\text { technique }\end{array}$ & & $\begin{array}{l}-1971 / 72: \\
\text { System organiser } \\
\text { course }\end{array}$ \\
\hline $\begin{array}{l}\text { - 1970: Mihály Pollack } \\
\text { Technical College (PMMF) } \\
\text { - (2004: Pécsi } \\
\text { Tudományegyetem, PTE) }\end{array}$ & & $\begin{array}{l}\text { - (1971: Computer } \\
\text { technique) }\end{array}$ & $\begin{array}{l}\text { - 1987: Computer } \\
\text { engineering - with } \\
\text { mechanical } \\
\text { engineering. and } \\
\text { building industrial } \\
\text { sections }\end{array}$ & $\begin{array}{l}\text { - 1992: } \\
\text { Engineering } \\
\text { informatics course - } \\
\text { with different } \\
\text { specializations }\end{array}$ \\
\hline $\begin{array}{l}\text { - 1972: Miklós Ybl Technical } \\
\text { College (YMÉMF) } \\
\text { - (2016: Szent István } \\
\text { Egyetem, SZIE) }\end{array}$ & $\begin{array}{l}\text { - before 1972: } \\
\text { Computer } \\
\text { technique }\end{array}$ & $\begin{array}{l}\text { - (1972: Computer } \\
\text { technique) }\end{array}$ & & \\
\hline
\end{tabular}


The above tables can provide us with interesting information regarding the introduction of courses.

Table 1 is about those higher education institutions that were the first to introduce independent computer-oriented courses by 1972 . To reiterate the above, we can establish the following:

- Strong personalities capable of establishing schools launched computer-oriented courses quite early on: László Kalmár introduced the Applied mathematician course at the University of Szeged in 1957 and Béla Krekó introduced the Planmathematician economist course at the Karl Marx University of Economics in 1960.

- Two different examples are about external compelling demands. The Computer technician course launched at the Kálmán Kandó Technical College in 1970 was a response to the strong demand for professionals shown by computer centres. The System engineer course launched at the NME College Faculty of Dunaújváros in 1971 was primarily aimed at providing professionals for the local Danube Iron Works.

- In 1972, as a result of the increased external demand for computer experts with university degrees, the Programmer mathematician course launched by ELTE and the science-universities of Szeged and Debrecen were the result of the internal crystallisation of their respective curricula. The Ministry of Culture even required these universities to provide this form of education, and they soon launched courses with harmonized curricula. Later on, these universities (again with harmonised curricula) based their university-level Program developer mathematician courses on this first initiative. (This created a 5-year university level training that functioned for 35 years; as opposed to the Bologna system, where the first three years provide only a college-level (cf. the university-level Programmer mathematician course). In both cases students had the possibility to exit after 3 years with a college degree).

The technical-oriented education institutions figuring in Tables 2-4 initially taught the applied computer sciences required by their respective profiles. The industry (and the market) had an increasingly intensive demand for the education of professionals with a thorough knowledge of informatics and adept at solving the problems incurred in the given sectors. With this external demand, the modernisation and specialisation of information technology-oriented subjects at technological education institutions also underwent strong internal development at a high rate. This led to the creation of the reference curricula of Engineering informatics courses: 
- The Informatics course launched at the BME's Faculty of Electrical Engineering in the 1986/87 school year, together with the Engineering informatics course that it developed into by 1991, was the national university standard, and

- The Engineering informatics course launched by the Kálmán Kandó Technical College in the 1988/89 school year was the college-level sample.

As shown by the above tables, the Engineering informatics course was taught at all universities and colleges by 1993 on the basis of the above college and university examples, taking into account the unique features of the various technological institutions.

\section{The similarities and differences of the histories, the connections between professors}

The information on the beginnings of computer-oriented education has a lot to teach us. Although all histories are unique, they have similar strains and content and the connections between the actors tie them all together.

The initial periods of the education institutions that started teaching computer sciences at different times are quite different from each other. On the one hand, the material to be taught continuously expanded as computer sciences developed and the availability of computers and software in Hungary (and its accessibility to students) was constantly expanding. On the other hand, teachers and the experts in the field of applied computer sciences published an increasing amount of useful materials, meaning that those who started teaching the subject at a later time were helped along in developing their topics by targeted technical books. Moreover, the demands of the ever broadening and selective market also underwent significant changes, and the diversity of the composition, interests, technical background, and connections of the respective teaching staff at the various education institutions provided for different topics, even at identical times. There is even a difference in the method by which the institutions introduced the teaching of various computer-related subjects. ELTE and the university of Debrecen started off by applying the principle of gradualism starting from the mid-1960s: they integrated it into certain other subjects and held seminars and special classes, after which it became an elective and finally a separate subject. (There were similar examples of this practice elsewhere as well.) However, as mentioned above, the BME's rigid curriculum made it quite difficult to introduce new courses.

It is also interesting to work out, at least in theory, the relationships between the contemporary Hungarian institutions and their teachers. Nobody doubts that the roots of the network of computer-oriented education in Hungary stem from Hungarian Academy 
of Sciences' Cybernetics Research Group. Many of the people who built the M-3 also had teaching positions and/or held lectures in higher education institutions. In addition, the computer sciences professors from many education institutions also came into contact with the M-3. It must also be noted that during the development of the various programs for the M-3, the Research Group's employees launched research in areas of computer application (e.g. economic applications, operations research, computational linguistics) where the results were subsequently used in the material taught by the colleges and universities.

László Kalmár, who organised his legendary seminary in 1956 by involving teachers, students, and aspiring talents from Szeged, played a prominent role in the network of personal relationships. Although both he, his colleagues, and his first students ran their first programs in Budapest (on the M-3), the spirit of the "Szeged School" was unequivocally defined by Kalmár's interests, knowledge, and personality. His professional aura could not be constrained by the walls of any one institution. He was also a frequent guest at the Cybernetics Research Group, which was like a second home for him. But he also frequented ELTE and the university of Debrecen. Every half-year he would also look up the Számok centre. Furthermore, his contribution to spreading computer application in a wide variety of areas in Hungary - from linguistics through biology and medical professions to industry - is also great. His helpfulness, wide range of interests, and legendary ability to see the essence of things also helped him find the solutions to numerous, non-mathematical related problems. László Kalmár was a living catalyst between disciples of the science and the professors and users of computer sciences. We mentioned earlier that he visited the Danube Iron Works several times in search of application-related tasks. It is no accident that the first of his students to graduate ended up at the Iron Works and then at the College in Dunaújváros. We naturally also met students of his at other universities9. He is thus a root with a multitude of branches in the network of actors involved in the teaching of computer sciences.

The oft-times intertwined history of the early predecessors of today's higher education institutions also acted as a catalyst for pervading the spirit of the original institution. For example, the book mentioned the fact that many Hungarian education institutions consider the Banská Štiavnica Mining Institution or the University of Trnava as their earliest predecessors. We must also mention the predecessor to the University of Szeged, the University of Cluj-Napoca (established in 1872), from where the majority of

\footnotetext{
${ }^{9}$ The author (as a student of László Kalmár) actively participated in teaching topics of Artificial Intelligence at universities and colleges for 25 years, starting from 1993. She was a guest lecturer at ELTE; a lecturer at the Óbudai Egyetem and its predecessors; and taught at the predecessor of the Dunaújvárosi Egyetem. She was moreover a contracted lecturer also at other institutions and held two 2-week lecture series at the Babes-Bolyai University in Cluj-Napoca.
} 
Hungarian teachers and students left in 1919 - generally carrying the spirit of the University with them to other Hungarian universities. Hungarian educators also worked at more than one institution, which added colour to the palette of education and contributed to the unification of teaching materials. - Moreover an increasing number of guest lecturers could be included in the courses and the students could perform practical training at more and more factories and institutions.

Finally, mention must be made of the professors' contemporary meetings and conferences that were very important venues for the exchange of ideas in the world without internet. Starting from 1972, the representatives of Hungarian universities met regularly every year to harmonise their topics. The first Hungarian computer education conferences were held in Visegrád (1974), Pécs (1978), and Siófok (1981). The NJSZT then organised national conferences entitled Programming Systems in 1972, 1975, 1978, 1980, and 1984. Starting in 1993, the Informatics in Higher Education (IF) conference series has been held every three years in Debrecen; from the very beginning, it has been a useful forum for all IT lecturers (the last one was held in August 2017).

\section{Closing thoughts}

The previous chapters provided a look at the special history of computeroriented higher education in Hungary. The author would again like to thank the work of those 130 collaborators who enthusiastically helped in collecting the materials used for preparing the document that forms the basis of this paper, even undertaking to work on entire (or parts of) chapters. (Sadly, a number of them have since passed away.) - Here the author expresses her thanks to Bálint Dömölki for revising both the book and this paper.

We must finally mention that the IT History Forum has been compiling a Data Archive since 2013, which is accessible at the website http://itf2.njszt.hu. The Data Archive is a "digitalized collection of information that is continuously growing and which includes the information, facts, and documents worthy of mention in the Hungarian history of informatics, pertaining to important figures, products, institutions, events, and published materials. With its help, users can look up the biographies, writings, and creations of prominent personalities. In fact, some of the elder persons talk about their lives in the form of video reports. We can find information on the types of IT products that were developed in Hungary prior to 1990 and can get a taste of the Hungarian conferences..." (Our source book titled 'A számitástechnika felsőfokú oktatásának kezdetei' is also available in the Archive: http://itf2.njszt.hu/324rtr4/uploads/Sztech164x233-1.pdf.) 
As the person responsible for the Persons ['Személyek'] section of the Data Archive ['Adattár'], the author is proud to note that of 300 persons figuring in the list of names included in the source book, almost half can be found under the "Who is Who" ['Ki kicsoda'] or the "Who aren't with us" ['Akik már...'] subsection. - The Data Archive allows both the contemporary actors and the younger generations to use its basic information as they look to the future of computing. 